\section{High Carbon Dioxide Atmospheres Affect Stored 'Thompson Seedless' Table Grapes}

\author{
Carlos H. Crisosto ${ }^{1}$, David Garner, and Gayle Crisosto \\ Department of Pomology, University of California at Davis, Kearney \\ Agricultural Center, 9240 South Riverbend Avenue, Parlier, CA 93648
}

Additional index words. controlled atmosphere, Vitis vinifera, $\mathrm{SO}_{2}$ alternative, maturity, off flavor, storage potential

\begin{abstract}
Efficacy of controlled atmosphere (CA) conditions for decay control in 'Thompson Seedless' table grapes was evaluated during the 1998-2000 seasons. During the 1998 season, early $(16.5 \%$ soluble solids concentration $=$ SSC $)$ and late harvested (19\% SSC) grapes were exposed to $5 \%, 10 \%, 15 \%, 20 \%$, or $25 \% \mathrm{CO}_{2}$ combined with $3 \%, 6 \%$, and $12 \% \mathrm{O}_{2}$. In 1999 and $2000,10 \%$ or $15 \% \mathrm{CO}_{2}$ combined with $3 \%, 6 \%$, or $12 \% \mathrm{O}_{2}$ were used. In all trials, fruit were initially $\mathrm{SO}_{2}$ fumigated and air-stored grapes were used as controls. Storage atmospheres did not affect SSC, titratable acidity (TA), or sugar-to-acid ratio (SSC : TA). The main storage limitations for early harvested 'Thompson Seedless' table grapes were "off flavor" and rachis and berry browning development, which resulted from exposure to $>10 \% \mathrm{CO}_{2}$. However, $\geq 15 \% \mathrm{CO}_{2}$ was needed to control total decay and nesting development independent of $\mathrm{O}_{2}$ concentrations. High carbon dioxide atmospheres (15\% to $25 \%)$ were more effective in decay control without detrimental effects on quality when late harvested grapes were used. The combination of $15 \% \mathrm{CO}_{2}$ with $3 \%, 6 \%$, or $12 \% \mathrm{O}_{2}$ is suggested for up to 3 months storage only for late harvested 'Thompson Seedless' table grapes; it should not be used for early harvested grapes.
\end{abstract}

The most important table grape cultivar worldwide is 'Thompson Seedless' and it is marketed nearly year-round throughout the world. For example, in 2000, California produced $\approx 224 \mathrm{t}$, and in 2001 , Chile produced $\approx 176 \mathrm{t}$ (Chilean Fresh Fruit Association, personal communication). Controlled atmospheres (CA) with elevated $\mathrm{CO}_{2}$ concentrations have been shown to control decay development on some commodities without affecting quality attributes during transport, storage, or both. Optimal CA combinations have been developed for different species, and even cultivars within the same species (Kader, 1997; Lidster et al., 1990; Smock, 1979).

Preliminary CA work has been done on other table grape cultivars such as 'Ribier' and 'Razaki' (Eris et al., 1993), South African cultivars (Laszio, 1985), 'Emperor' (Uota, 1957), and some Italian cultivars (Cimino et al., 1987). A few studies have been done on 'Thompson Seedless' (Berry and Aked, 1997; Nelson, 1969; Yahia et al., 1983). Nelson (1969) found that berry internal browning incidence overcame the potential benefits of CA in his early trials with 'Thompson Seedless' table grapes from the Coachella Valley of California. Yahia et al. (1983) using 5\% $\mathrm{CO}_{2}$ $+2 \% \mathrm{O}_{2}$, reported that Botrytis cinerea decay (gray mold) and internal berry browning were the main deterioration symptoms beyond 8 weeks storage. In research carried out in En-

Received for publication 23 July 2001. Accepted for publication 7 Mar. 2002.

${ }^{1}$ To whom reprint requests should be addressed. Tel.: (559) 646-6596; Fax: (559) 646-6593. E-mail address: carlos@uckac.edu gland with 'Thompson Seedless' table grapes from Egypt, Berry and Aked (1997) observed an inhibition of Botrytis cinerea by exposure to a CA of $15 \% \mathrm{CO}_{2}+5 \% \mathrm{O}_{2}$.

Botrytis cinerea (gray mold) is the primary postharvest pathogen of table grapes in California. Botrytis rot on grapes can be diagnosed by its characteristic "slipskin" that develops on the surface of infected berries. Areas of the berry skin infected with Botrytis are brown in color and slip freely when rubbed with the fingers, leaving the firm underlying pulp exposed (Luvisi et al., 1992). Uncontrolled infections result in the development of aerial mycelium that spreads to adjacent berries. These pockets of decay that develop are called "nests". Rhizopus sp. and Aspergillis niger can infect table grapes, but they do not develop during storage at low temperatures. Penicillium sp. do not infect healthy grapes, but may develop on wounds. Cladosporium herbarum, Alternaria sp., and Stemphylium sp. infections develop slowly in cold storage and can be distinguished from Botrytis by the black lesions they form.

Our objective was to determine optimal $\mathrm{CO}_{2}$ and $\mathrm{O}_{2}$ levels to control gray mold without affecting soluble solids concentration (SSC), titratable acidity (TA), flesh firmness, rachis or berry condition, or flavor in 'Thompson Seedless' table grapes.

\section{Materials and Methods}

Commercially harvested 'Thompson Seedless' table grapes were field packaged in cluster bags that were placed in corrugated cartons, and then fumigated with sulfur dioxide (250 ppm-hour) during precooling (Luvisi et al., 1992). Grapes were then transported to the F. Gordon Mitchell Postharvest Laboratory at the Kearney Agricultural Center in Parlier, Calif. and forced air-cooled again to a berry temperature of $\approx 0{ }^{\circ} \mathrm{C}$. After cooling, grapes were divided into storage treatments. Grapes were stored at $0{ }^{\circ} \mathrm{C}$ in 338 -L sealed aluminum tanks under a continuous flow of either air or the desired mixture of $\mathrm{CO}_{2}$ and $\mathrm{O}_{2}$.

During the 1998 season, 'Thompson Seedless' table grapes were harvested according to their SSC at early (16.5\%) or late (19\%) commercial maturity. Grape samples were stored in air and $15 \mathrm{CA}$ combinations for up to 3 months at $0{ }^{\circ} \mathrm{C}$. The $15 \mathrm{CA}$ combinations were $5 \%$, $10 \%, 15 \%, 20 \%$, or $25 \% \mathrm{CO}_{2}$ combined with $3 \%, 6 \%$, or $12 \% \mathrm{O}_{2}$. In the 1999 season, 'Thompson Seedless' table grapes harvested at $20 \%$ SSC were commercially packed and stored at $0{ }^{\circ} \mathrm{C}$ in 338 -L sealed aluminum tanks under a continuous flow of either air or combinations of $10 \%$ or $15 \% \mathrm{CO}_{2}$ combined with $3 \%, 6 \%$, or $12 \% \mathrm{O}_{2}$. In the 2000 season, 'Thompson Seedless' table grapes with $20 \%$ SSC were harvested from six different vineyards having historically "high" incidence of decay. Grapes were packaged and handled as previously described. After cooling, the fruit were stored at $0{ }^{\circ} \mathrm{C}$ in 338-L sealed aluminum tanks under a continuous flow of either $10 \% \mathrm{CO}_{2}+3 \% \mathrm{O}_{2}, 15 \% \mathrm{CO}_{2}$ $+3 \% \mathrm{O}_{2}, 15 \% \mathrm{CO}_{2}+12 \% \mathrm{O}_{2}$, or air as previously described.

In the three seasons, air storage was used as a control for all of the experiments. Flow rates and gas mixtures were established using a mixing board with micro-metering valves (Post Harvest Research, Davis, Calif.). Supply and exhaust gas $\mathrm{O}_{2}$ and $\mathrm{CO}_{2}$ composition was monitored using an paramagnetic oxygen analyzer (model S-3A/II, Ametek Thermox, Pittsburgh) and an infrared gas analyzer (model VIA-510; Horiba, Irvine, Calif.) for $\mathrm{CO}_{2}$.

Quality evaluations. In the three seasons, five clusters (replications) per treatment were removed every month (4 weeks) for quality evaluations, including rachis browning, berry browning, Botrytis development, berry firmness, SSC, and TA. Rachis browning development was evaluated using the following subjective scoring system: 1 ) healthy = entire rachis including the cap stems (merging point between berries and rachis) green; 2) slight = only cap stems showing browning; 3 ) moderate = cap stems and secondary rachis showing browning; and 4) severe = cap stems, secondary and primary rachis completely brown (Crisosto et al., 2001). All brown berries were removed and weighed, and berry browning was expressed as a percentage of cluster weight. Botrytis rot was identified visually by its characteristic brown lesions and "slipskin." For each cluster, the number of nests of Botrytis present was noted. Clusters were considered to have formed a nest if mycelia actively grew from one berry to at least one other adjacent berry. In addition, all infected berries were removed, weighed, and decay expressed as a percentage of cluster weight. In the 1999 season, nesting and total decay were evaluated immediately after cold 
storage, and then again after $3 \mathrm{~d}$ at $20^{\circ} \mathrm{C}$, simulating a retail display period.

Berry firmness was measured on 10 healthy berries per replication by first removing the skin from the cheek with a razor blade, then measuring the force of penetration in grams using a U.C. firmness tester (Western Industrial Supply, San Francisco) with a 3-mm tip. Ten berries from each replication were pooled, pressed through cheesecloth to extract the juice, and SSC was measured with a temperature compensating refractometer (model ATC-1, Atago Co., Tokyo). The TA was measured with an automatic titrator (Radiometer, Copenhagen, Denmark) and reported as percent tartaric acid.

A taste evaluation focusing on "off flavor" development was carried out by six trained judges only during the first season. Judges were screened for their acuity in perceiving "off flavor" using a triangle test (O'Mahony, 1986). The "off flavor" of 12 berries per treatment was evaluated using a binary response of "yes" or "no." Each grape sample consisted of a whole berry.

In the 1998 experiment, we used a factorial design, using $\mathrm{CO}_{2}$ and $\mathrm{O}_{2}$ levels as factors, with three replications. In the 1999 and 2000 experiments, we used a completely randomized design with nine replications. The data were subjected to analysis of variance
(ANOVA) prior to a least significant differences (LSD) means separation using the SAS program. The SAS statistical software (SAS Institute, Cary, N.C.) was used for these analyses.

\section{Results and Discussion}

Quality evaluations. During the 1998 season, high $\mathrm{CO}_{2}$ treatment suppressed gray mold growth on early (16.5\% SSC) and late (19\% SSC) harvested 'Thompson Seedless' table grapes. Botrytis infection in the first month ranged from none to $5.5 \%$ for air-stored early harvested grapes. For late harvested grapes, Botrytis infection ranged from $1 \%$ to $32.8 \%$. In all cases, decay incidence was not related to $\mathrm{O}_{2}$ or the $\mathrm{O}_{2}-\mathrm{CO}_{2}$ interaction (Table 1). In all of the evaluations, the beneficial effect of $\geq 10 \% \mathrm{CO}_{2}$ on suppression of Botrytis decay (total berries infected) was evident (Fig. 1). For both harvest dates, there were no significant differences in decay incidence between grapes stored at $10 \%$ to $25 \% \mathrm{CO}_{2}$, except after 2 months in storage when decay was better controlled by $15 \% \mathrm{CO}_{2}$ than $10 \% \mathrm{CO}_{2}$ on late harvested grapes. Since Botrytis decay was only affected by $\mathrm{CO}_{2}$ concentrations, ANOVA and LSD analysis were carried out excluding $\mathrm{O}_{2}$ as a treatment. For both early and late harvested grapes, Botrytis development was not

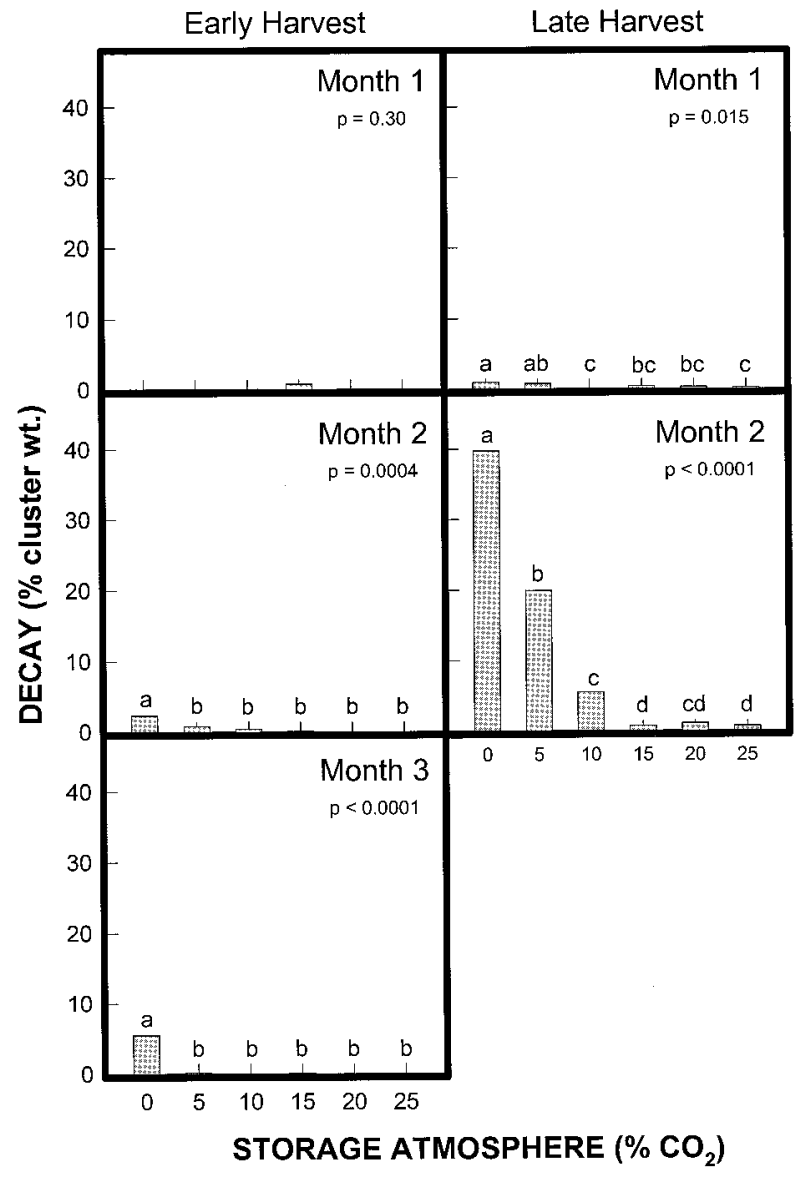

Fig. 1. Decayed berries, expressed as a percentage of cluster fresh weight, of early (16.5\% SSC) and late (19\% SSC) 1998 harvested 'Thompson Seedless' table grapes after 1,2 , and 3 months storage in different $\mathrm{CO}_{2}$-enriched atmospheres. Different letters indicate a significant difference between storage atmospheres by $\mathrm{LSD}_{0.05}$. visible until the second month of storage, when it was significantly higher on the airstored grapes than any of the $\mathrm{CO}_{2}$ storage treatments. In all of the cases, the weight of decayed berries was significantly reduced when $\mathrm{CO}_{2}$ concentrations were $\geq 15 \%$ during storage (Fig. 1). Similar results were reported for Monilinia fructicola decay on sweet cherries (Tian et al., 2001).

For early and late harvested grapes, the $\mathrm{CO}_{2}$ and $\mathrm{O}_{2}$ combinations tested did not significantly affect SSC, TA or SSC : TA (data not shown). Berry browning became commercially important $(>5.0 \%)$ by the second month on early (16.5\% SSC) harvested grapes. This browning was also only related to $\mathrm{CO}_{2}$ concentrations (Table 2). Air-stored early and late harvested grapes did not develop commercially important berry browning even after 3 months storage. However, berry browning was accelerated by $\geq 15 \% \mathrm{CO}_{2}$ after 2 months in storage (Fig. 2). None or very slight berry browning was observed on late harvested $(19 \%$ $\mathrm{SSC}$ ) grapes, except those exposed to $25 \%$ $\mathrm{CO}_{2}$, which exhibited $\approx 11 \%$ berry browning after 2 months in storage.

For early harvested grapes, rachis browning became commercially important (score $\geq 2.0$ ) by the first month (Fig. 3). For grapes at both maturity stages, $\mathrm{O}_{2}$ and the interaction between $\mathrm{O}_{2}$ and $\mathrm{CO}_{2}$ was not related to the onset of rachis browning (Table 3). At all evaluation times, $\geq 10 \% \mathrm{CO}_{2}$ increased rachis browning for early harvested grapes. Late harvested grapes tolerated high $\mathrm{CO}_{2}$ very well. Only late harvested grapes stored in $\geq 20 \%$ $\mathrm{CO}_{2}$ showed signs of rachis browning (score $\geq 2.0$ ) after 2 months. Because of a high incidence of decay, rachis condition of late harvested grapes was not evaluated after 3 months storage.

Table 1. Probabilities for significance in the analysis of variance for the effects of carbon dioxide $\left(\mathrm{CO}_{2}=0 \%, 5 \%, 10 \%, 15 \%, 20 \%\right.$, and $\left.25 \%\right)$ and oxygen $\left(\mathrm{O}_{2}=0 \%, 3 \%, 6 \%, 12 \%\right.$, and $\left.21 \%\right)$ concentrations on the percentage Botrytis rot of early (16.5\% SSC) and late (19\% SSC) harvested 'Thompson Seedless' table grapes during cold storage at $0{ }^{\circ} \mathrm{C}, 1998$.

\begin{tabular}{|c|c|c|c|c|c|}
\hline \multirow[b]{3}{*}{ Treatment } & \multicolumn{5}{|c|}{ Storage time } \\
\hline & \multicolumn{2}{|c|}{1 month } & \multicolumn{2}{|c|}{2 months } & \multirow{2}{*}{$\frac{3 \text { months }}{16.5 \% \mathrm{SSC}}$} \\
\hline & $16.5 \% \mathrm{SSC}$ & $19 \%$ SSC & $16.5 \% \mathrm{SSC}$ & $19 \% \mathrm{SSC}$ & \\
\hline \multicolumn{6}{|c|}{ Decay (\% by weight) } \\
\hline $\mathrm{CO}_{2}$ & 0.27 & 0.047 & 0.013 & $<0.0001$ & 0.009 \\
\hline $\mathrm{O}_{2}$ & 0.26 & 0.60 & 0.30 & 0.62 & 0.31 \\
\hline $\mathrm{CO}_{2} \times \mathrm{O}_{2}$ & 0.72 & 0.54 & 0.16 & 0.80 & 0.42 \\
\hline
\end{tabular}

Table 2. Probabilities for significance in the analysis of variance for the effects of carbon dioxide $\left(\mathrm{CO}_{2}=0 \%, 5 \%, 10 \%, 15 \%\right.$, $20 \%$, and $25 \%)$ and oxygen $\left(\mathrm{O}_{2}=0 \%, 3 \%, 6 \%, 12 \%\right.$, and $21 \%$ ) concentrations on berry browning of early harvested (16.5\% SSC) 'Thompson Seedless' table grapes during cold storage at $0{ }^{\circ} \mathrm{C}, 1998$.

\begin{tabular}{lccc}
\hline \hline & \multicolumn{3}{c}{ Storage time } \\
\cline { 2 - 4 } Treatment & 1 month & 2 months & 3 months \\
\hline \multicolumn{4}{c}{ Berry browning (\% by weight) } \\
$\mathrm{CO}_{2}$ & 0.29 & 0.017 & $<0.0001$ \\
$\mathrm{O}_{2}$ & 0.15 & 0.47 & 0.39 \\
$\mathrm{CO}_{2} \times \mathrm{O}_{2}$ & 0.40 & 0.11 & 0.32 \\
\hline
\end{tabular}




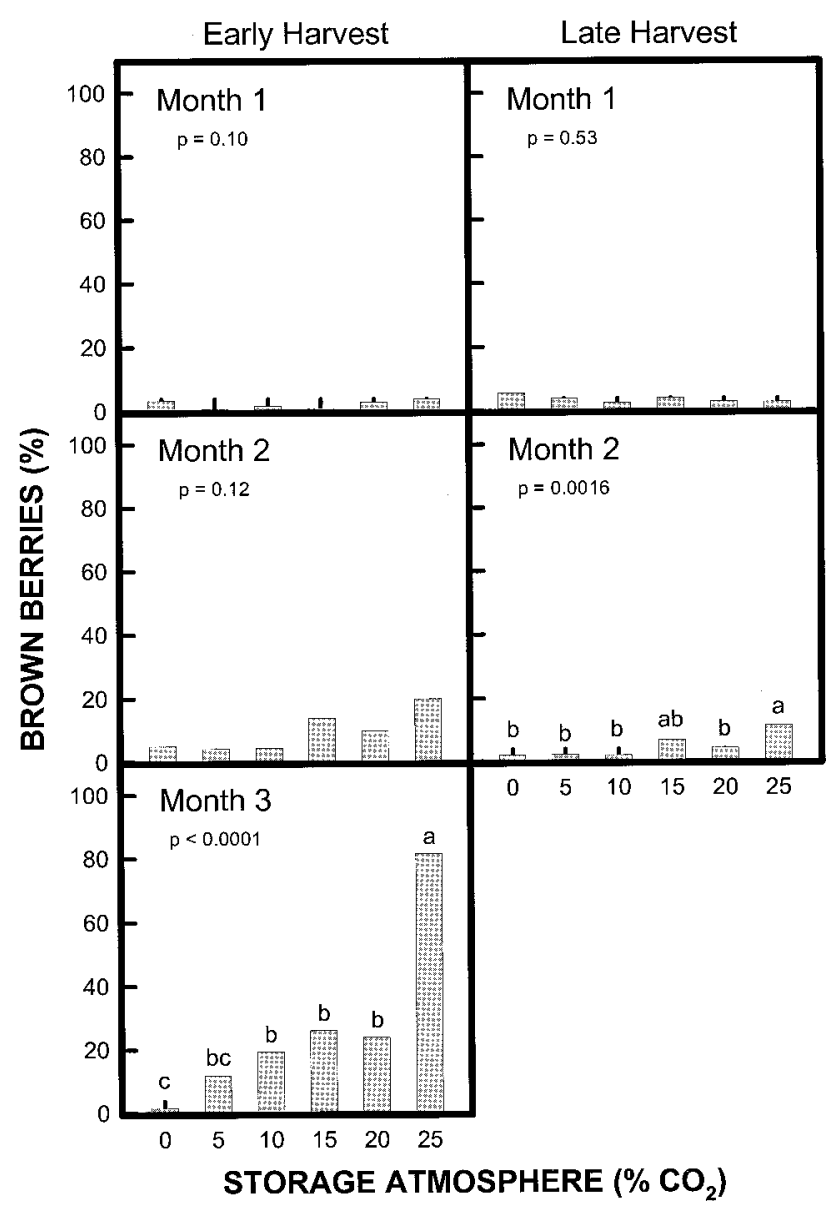

Fig. 2. Brown berries, expressed as a percentage of cluster fresh weight, of early (16.5\% SSC) and late (19\% SSC) 1998 harvested 'Thompson Seedless' table grapes after 1, 2, and 3 months storage in different $\mathrm{CO}_{2}$-enriched atmospheres. Different letters indicate a significant difference between storage atmospheres by $\mathrm{LSD}_{0.05}$.

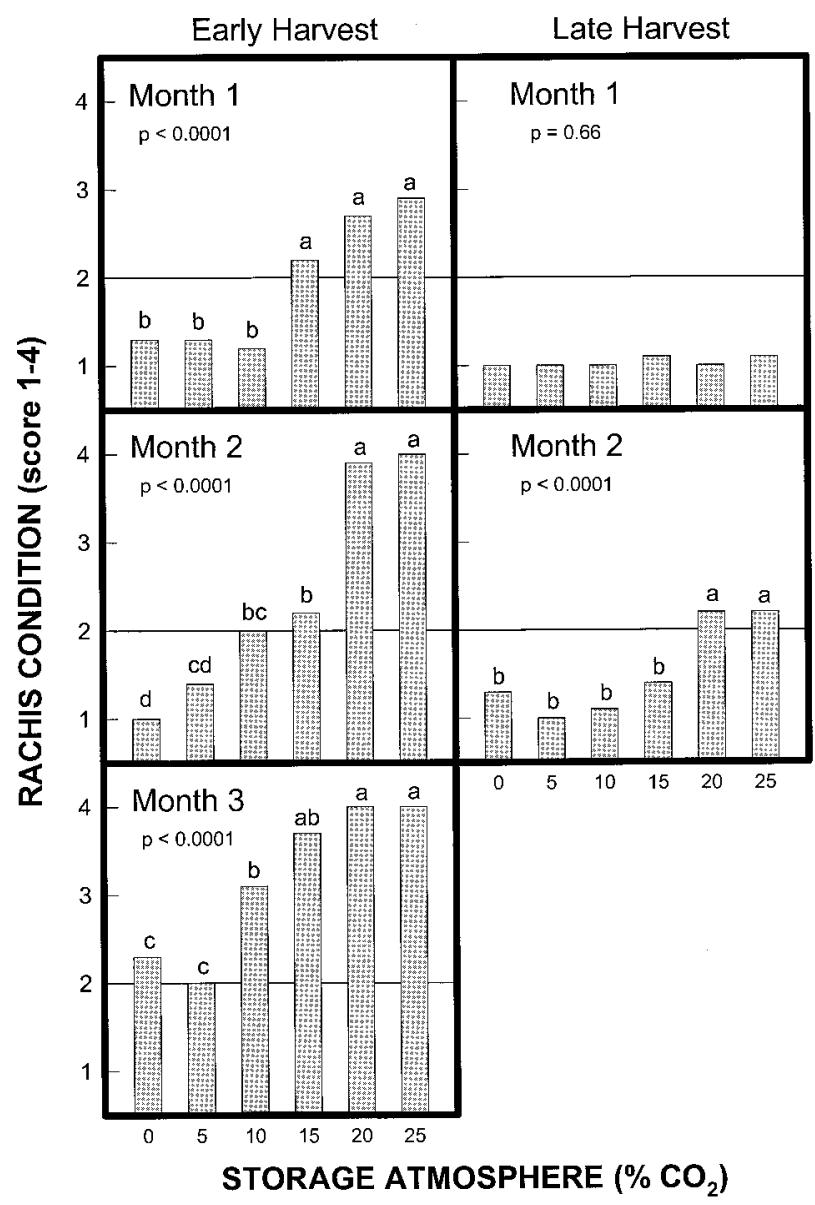

Fig. 3. Rachis browning score of early (16.5\% SSC) and late (19\% SSC) 1998 harvested 'Thompson Seedless' table grapes after 1, 2, and 3 months storage in different $\mathrm{CO}_{2}$-enriched atmospheres where $1=$ healthy stems with no browning; 2 = brown cap stems, laterals and rachis green; 3 = brown cap stems and laterals, rachis green; $4=$ cap stems, laterals and main rachis brown. Different letters indicate a significant difference between storage atmospheres by $\operatorname{LSD}_{0.05}$.
Judges on a trained panel perceived development of "off flavor" in "Thompson Seedless' table grapes, but its presence was not related to $\mathrm{O}_{2}$ concentration. The development of "off flavor" evaluated on early and late harvested grapes after one month at $0{ }^{\circ} \mathrm{C}$ followed by $2 \mathrm{~d}$ at $20^{\circ} \mathrm{C}$ was only related to $\mathrm{CO}_{2}$ levels (Fig. 4). Early harvested grapes had more "off flavors" than late harvested grapes. In the evaluation carried out after 2 months at $0{ }^{\circ} \mathrm{C}$ followed by $2 \mathrm{~d}$ at $20{ }^{\circ} \mathrm{C}$, $\approx 35 \%$ of the judges detected "off flavor" in air- and $10 \% \mathrm{CO}_{2}$-stored grapes, while $\approx 60 \%$ to $80 \%$ of the judges detected "off flavor" in early harvested grapes stored in $\geq 15 \% \mathrm{CO}_{2}$. None of the judges detected "off flavor" in grapes stored in $5 \% \mathrm{CO}_{2}$. In all of the evaluations, grapes from the $5 \% \mathrm{CO}_{2}$ treatments had similar or less "off flavor" development than air-stored grapes.

"Off flavor" was induced by CA treatments when grapes at both maturities were stored in $\geq 15 \% \mathrm{CO}_{2}$. Differences in "off flavor" development between air-stored early and late har-

Table 3. Probabilities for significance in the analysis of variance for the effects of carbon dioxide $\left(\mathrm{CO}_{2}=0 \%, 5 \%, 10 \%, 15 \%, 20 \%\right.$, and $25 \%)$ and oxygen $\left(\mathrm{O}_{2}=0 \%, 3 \%, 6 \%, 12 \%\right.$, and $\left.21 \%\right)$ concentrations on rachis browning of early harvested $(16.5 \% \mathrm{SSC})$ ' Thompson Seedless' table grapes during cold storage at $0{ }^{\circ} \mathrm{C}, 1998$.

\begin{tabular}{lccc}
\hline \hline & \multicolumn{3}{c}{ Storage time } \\
\cline { 2 - 4 } Treatment & 1 month & 2 months & 3 months \\
\hline \multicolumn{3}{c}{ Rachis browning score } \\
$\mathrm{CO}_{2}$ & $<0.0001$ & $<0.0001$ & $<0.0001$ \\
$\mathrm{O}_{2}$ & 0.17 & 0.93 & 0.63 \\
$\mathrm{CO}_{2} \times \mathrm{O}_{2}$ & 0.50 & 0.29 & 0.48 \\
\hline
\end{tabular}

${ }^{2}$ Rachis score: 1 = healthy, 2 = slight browning of the cap stems, $3=$ browning of the cap stems and lateral stems, and $4=$ severe browning of the cap stems, lateral stems and main rachis.

vested grapes can be explained by differences in chemical composition (such as aroma compounds and hydroxycinnamoyl esters) due to their maturity stages (Peynaud and RibereauGayon, 1971; Robredo et al., 1991; Romeyer et al., 1983). These chemicals may be oxidized during storage, producing an "off flavor." As grapes mature, concentrations of these chemical compounds are reduced; thus, "off flavor" development during storage is minimized. The beneficial effect of $5 \% \mathrm{CO}_{2}$ storage treatment on reducing "off flavor" development over air storage is more apparent for early harvested grapes and grapes prone to "off flavor" development. It is important to point out that the same percentage of judges perceiving "off flavor" in a trained panel would not be the same as the percentage of consumers in a consumer test detecting "off flavor" at these levels. Based on previously published information (Ke et al., 1991; O'Mahony, 1986), we predict that the percentage of consumers detecting "off flavor" from these treatments would be lower than for our trained judges. In general, "off flavor" and rachis browning development were induced in early and late harvested grapes by $>10 \% \mathrm{CO}_{2}$ and $>15 \% \mathrm{CO}_{2}$, respectively, while decay was limited at $\geq 10 \% \mathrm{CO}_{2}$. 


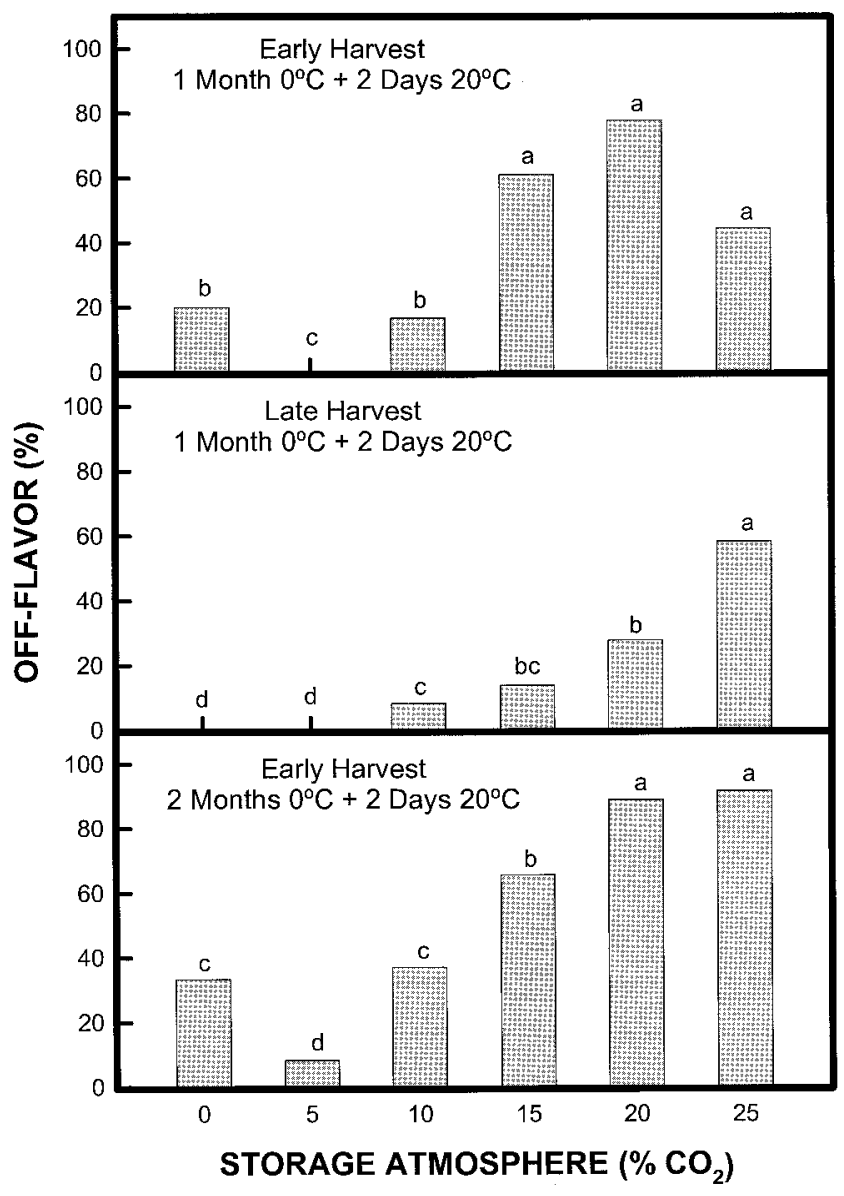

Fig. 4. Off flavor development of early (16.5\% SSC) and late (19\% SSC) 1998 harvested 'Thompson Seedless' table grapes after 1 or 2 months storage in different $\mathrm{CO}_{2}$-enriched atmospheres at $0{ }^{\circ} \mathrm{C}$ followed by $2 \mathrm{~d}$ in air at $20^{\circ} \mathrm{C}$ prior to tasting by a trained panel. Different letters represent a statistical difference between storage atmospheres by pair wise binomial analysis $\left(\mathrm{X}^{2}\right)$ at $P<0.05$.
Table 4. Quality of late harvested (20\% SSC) 'Thompson Seedless' table grapes after 1,2 , and 3 months storage at $0{ }^{\circ} \mathrm{C}$ in different CA combinations and after $3 \mathrm{~d}$ display at $20^{\circ} \mathrm{C}, 1999$.

\begin{tabular}{|c|c|c|c|c|c|}
\hline \multicolumn{2}{|c|}{$\begin{array}{c}\text { Storage } \\
\text { atmosphere }\end{array}$} & \multicolumn{2}{|c|}{$\begin{array}{l}\text { After storage } \\
\text { at } 0^{\circ} \mathrm{C} \\
\end{array}$} & \multicolumn{2}{|c|}{$\begin{array}{c}\text { After storage } \\
\text { plus } 3 \mathrm{~d} \text { at } 20^{\circ} \mathrm{C}\end{array}$} \\
\hline $\begin{array}{l}\mathrm{CO}_{2} \\
(\%) \\
\end{array}$ & $\begin{array}{l}\mathrm{O}_{2} \\
(\%)\end{array}$ & $\begin{array}{c}\text { Rachis score } \\
(1-4)^{\mathrm{z}}\end{array}$ & $\begin{array}{c}\text { Nests (no. } \\
\text { per cluster) }\end{array}$ & $\begin{array}{l}\text { Nests (no. } \\
\text { per custer) }\end{array}$ & $\begin{array}{l}\text { Decay } \\
(\% \text { wt })\end{array}$ \\
\hline \multicolumn{6}{|c|}{1 month } \\
\hline 10 & 3 & 1.0 & 0.0 & 0.0 & 4.0 \\
\hline 10 & 6 & 1.7 & 0.0 & 0.0 & 6.9 \\
\hline 10 & 12 & 1.0 & 0.0 & 0.0 & 6.3 \\
\hline 15 & 3 & 1.3 & 0.0 & 0.0 & 4.4 \\
\hline 15 & 6 & 1.7 & 0.0 & 0.0 & 4.1 \\
\hline 15 & 12 & 1.7 & 0.0 & 0.0 & 4.1 \\
\hline Air & & 1.7 & 0.0 & 0.0 & 25.2 \\
\hline$P$ value & & 0.33 & NS & NS & 0.0067 \\
\hline $\mathrm{LSD}_{0.05}$ & & NS & NS & NS & 10.6 \\
\hline \multicolumn{6}{|c|}{2 months } \\
\hline 10 & 3 & 2.3 & 0.3 & 0.3 & 1.6 \\
\hline 10 & 6 & 2.0 & 0.3 & 0.3 & 2.0 \\
\hline 10 & 12 & 2.0 & 0.0 & 0.0 & 2.4 \\
\hline 15 & 3 & 2.0 & 0.0 & 0.0 & 0.1 \\
\hline 15 & 6 & 1.7 & 0.0 & 0.0 & 0.4 \\
\hline 15 & 12 & 2.0 & 0.0 & 0.3 & $0.6 \mathrm{a}$ \\
\hline Air & & 1.3 & 0.7 & 1.0 & 10.3 \\
\hline$P$ value & & 0.12 & 0.27 & 0.038 & 0.0081 \\
\hline $\mathrm{LSD}_{0.05}$ & & NS & NS & 0.7 & 4.5 \\
\hline \multicolumn{6}{|c|}{3 months } \\
\hline 10 & 3 & 2.3 & 0.0 & 0.3 & 6.4 \\
\hline 10 & 6 & 2.3 & 0.3 & 0.7 & 9.9 \\
\hline 10 & 12 & 2.7 & 0.0 & 0.7 & 12.1 \\
\hline 15 & 3 & 3.0 & 0.0 & 0.3 & 3.2 \\
\hline 15 & 6 & 3.3 & 0.0 & 0.7 & 1.6 \\
\hline 15 & 12 & 2.7 & 0.0 & 0.7 & 5.9 \\
\hline Air & & 3.3 & 1.0 & 1.0 & 59.1 \\
\hline$P$ value & & 0.34 & 0.0004 & 0.33 & 0.0045 \\
\hline $\mathrm{LSD}_{0.05}$ & & NS & 0.4 & NS & 26.4 \\
\hline
\end{tabular}

${ }^{2}$ Rachis score: $1=$ healthy, 2 = slight browning of the cap stems, $3=$ browning of the cap stems and lateral stems, and $4=$ severe browning of the cap stems, lateral stems and main rachis.

Ns Nonsignificant.
During the 1999 season, berry browning of late harvested (20\% SSC) grapes was not observed during the 3-month storage period (data not shown). Rachis browning started to develop at the cap stems after the second month of cold storage. After 3 months storage, rachises from all of the treatments showed visible signs of dehydration. On all three evaluation dates, there were no significant differences in rachis browning among any of the treatments (Table 4).

The presence of nests of Botrytis after removal from storage and then display ( $3 \mathrm{~d}$ at $20{ }^{\circ} \mathrm{C}$ ) was not observed until the second month. After 2 months, there was significantly more nesting in air-stored grapes than CAstored grapes (Table 4). There were no significant differences in nesting development measured after cold storage between the CA treatments, although grapes stored in any of the CA treatments had fewer nests of decay than airstored grapes. After 2 months storage at $0{ }^{\circ} \mathrm{C}$ plus $3 \mathrm{~d}$ at $20{ }^{\circ} \mathrm{C}$ (display), there were more nests measured on grapes stored in air than in any of the CA treatments. After 3 months, grapes stored in CA had fewer nests at the time of removal than grapes stored in air. After 3 d at $20{ }^{\circ} \mathrm{C}$, nesting developed in all of the treatments with no significant differences between them. There was always less total decay (\% weight) measured after $3 \mathrm{~d}$ at $20^{\circ} \mathrm{C}$ in grapes from the CA treatments than in airstored grapes. After three months storage, there was $59 \%$ total decay in air-stored grapes and $<13 \%$ in grapes from the CA treatments.

During the 2000 season, as expected, there were no significant differences in firmness, SSC, TA, or SSC : TA between treatments. Berry browning was not observed in any of the treatments. All three CA treatments effectively controlled decay during the 3-month storage period. The late harvested grapes stored in air developed nests of decay after 2 months at $0{ }^{\circ} \mathrm{C}$ (Table 5). After 2 months storage, all of the clusters stored in air had nests of decay, while no nests had developed in any of the CA treatments. There was $22 \%$ and $42 \%$ total decay by weight in air-stored fruit after 2 and 3 months storage, respectively. Grapes stored in CA had less than $1.0 \%$ total decay.

Based on our three seasons of research, $\geq 15 \% \mathrm{CO}_{2}$ is necessary to control Botrytis decay on 'Thompson Seedless' table grapes. However, grape quality losses due to "off flavor" and rachis and berry browning were induced on early harvested grapes. Because of these potential quality problems, we do not recommend the use of CA for early harvested 'Thompson Seedless' table grapes. In the San Joaquin Valley (California) and Maipo and Aconcagua Valleys (Chile), 'Thompson Seedless' table grapes are harvested with SSC

Table 5. Effect of controlled atmosphere storage (CA) on decay of 'Thompson Seedless' table grapes after up to 3 months storage at $0{ }^{\circ} \mathrm{C}, 2000$.

\begin{tabular}{lccccccc}
\hline \hline & \multicolumn{3}{c}{ Nests (no. per cluster) } & & \multicolumn{3}{c}{ Decay (\% by wt) } \\
\cline { 2 - 3 } Treatment & 1 month & 2 months & 3 months & & 1 month & 2 months & 3 months \\
\hline Air & 0.0 & 0.8 & 1.0 & & 0.0 & 21.8 & 42.4 \\
$10 \% \mathrm{CO}_{2}+3 \% \mathrm{O}_{2}$ & 0.0 & 0.0 & 0.0 & & 0.0 & 0.0 & 1.1 \\
$15 \% \mathrm{CO}_{2}+3 \% \mathrm{O}_{2}$ & 0.0 & 0.0 & 0.0 & & 0.0 & 0.0 & 0.0 \\
$15 \% \mathrm{CO}_{2}+12 \% \mathrm{O}_{2}$ & 0.0 & 0.0 & 0.0 & & 0.0 & 0.1 & 0.2 \\
$P$ value & NS & 0.0001 & 0.0001 & & 0.42 & 0.0001 & 0.0001 \\
LSD $_{0.05}$ & NS & 0.1 & 0.8 & & NS & 5.0 & 5.1 \\
\hline
\end{tabular}

${ }^{\mathrm{z}}$ Average of six vineyards with historical records of high decay.

${ }^{\text {ss }}$ Nonsignificant. 
ranging from $16 \%$ to $21 \%$, with most being harvested at $18 \%$ SSC. For our research, we defined early harvested grapes as those with about $16 \%$ SSC and late harvested grapes as those nearing $20 \%$ SSC. Since late harvested 'Thompson Seedless' table grapes tolerate $15 \%$ $\mathrm{CO}_{2}$ very well, we suggest a $\mathrm{CA}$ of $15 \% \mathrm{CO}_{2}$ combined with $3 \%, 6 \%$, or $12 \% \mathrm{O}_{2}$ to limit Botrytis rot development without adversely affecting quality attributes.

\section{Literature Cited}

Berry, G. and J. Aked. 1997. Controlled atmosphere alternatives to the postharvest use of sulfur dioxide to inhibit the development of Botrytis cinerea in table grapes, p. 100. In: A.A. Kader (ed.). CA ' 97 Proc., Vol. 3, Postharvest Horticulture Series No. 17. Postharvest Outreach Program, Univ. of California, Davis.

Cimino, A., M. Mari, and A. Marchi. 1987. U.L.O. storage of table grapes and kiwifruit, p. 642646. In: Austrian Assn. Refrigeration and Air Conditioning (ed.). Vol. C., Proc. XVIIth Intl. Congr. Refrig., Vienna.

Crisosto, C.H., J.L. Smilanick, and N.K. Dokoozlian. 2001. Table grapes suffer water loss, stem browning during cooling delays. Calif. Agr. 55:39-42.
Eris, A., C. Turkben, M.H. Ozer, and J. Henze. 1993. A research on CA-storage of grape cultivars 'Alphonse Lavallee' and 'Razaki', p. 705710. Proc. 6th Intl. CA Res. Conf., Natural Resource, Agr. Eng. Serv.-71, Ithaca, N.Y., Cornell Univ.

Kader, A. 1997. A summary of CA and MAP requirements and recommendations for fruit other than apples and pears, p. 14. In: A.A. Kader (ed.). CA '97 Proc., Vol. 3, Postharvest Horticulture Series No. 17. Postharvest Outreach Program, Univ. of California, Davis.

Ke, D., L. Rodriguez, and A. Kader. 1991. Physiology and prediction of fruit tolerance to low oxygen atmospheres. J. Amer. Soc. Hort. Sci. 116:253-260.

Laszio, J.C. 1985. The effect of controlled atmosphere on the quality of stored table grapes. Decid. Fruit Grower 32:436-438.

Lidster, P.D., G.D. Blanpied, and R.K. Prange. 1990. Controlled-atmosphere disorders of commercial fruits and vegetables. Agr. Canada Publ. 1847/E.

Luvisi, D.A., H. Shorey, J. Smilanick, J. Thompson, B. Gump, and J. Knutson. 1992. Sulfur dioxide fumigation of table grapes. Univ. California, Div. Agr., and Natural Resources, Bul. 1932.

Nelson, K.E. 1969. Controlled atmosphere storage of table grapes. Proc. Natl. CA Res. Conf., Michigan State Univ., Hort. Rpt. 9:69-70.

O'Mahony, M. 1986. Sensory evaluation of food.
Marcel Dekker, New York.

Peynaud, E. and P. Ribereau-Gayon. 1971. The grape, p. 172-206. In: A.C. Hulme (ed.). The biochemistry of fruits and their products, vol. 2. Academic, New York.

Robredo, L.M., B. Junquera, M.L. GonzalezSanjose, and L.J.R Barron. 1991. Biochemical events during ripening of grape berries. Ital. J. Food Sci. 3:173-180.

Romeyer, F.M., J.J. Macheix, J.P. Goiffon, C.C. Reminiac, and J.C. Sapis. 1983. The browning capacity of grapes. 3. Changes and importance of hydroxycinnamic acid-tartaric acid esters during development and maturation of the fruit. J. Agr. Food Chem. 31:346-349.

Smock, R. 1979. Controlled atmosphere storage of fruits. Hort. Rev. 1:301-336.

Tian, S., Q. Fan, Y. Xu, F. Wang, and A. Jiang. 2001. Evaluation of the use of high $\mathrm{CO}_{2}$ concentrations and cold storage to control Monilinia fructicola on sweet cherries. Postharvest Biol. Technol. 22:53-60.

Uota, K. 1957. Preliminary study on storage of 'Emperor' grapes in controlled atmospheres with and without sulfur dioxide fumigation. Proc. Amer. Soc. Hort. Sci. 69:250-253.

Yahia, E.M., K.E. Nelson, and A.A. Kader. 1983. Postharvest quality and storage life of grapes as influenced by adding carbon monoxide to air or controlled atmospheres. J. Amer. Soc. Hort. Sci. 108:1067-1071. 